\title{
Cultivar-specific Apple Fruit Growth Rates in Vivo and Sink Activities in Vitro
}

\author{
Douglas D. Archbold \\ Department of Horticulture and Landscape Architecture, University of Kentucky, Lexington, \\ KY 40546-0091
}

\begin{abstract}
Additional index words. Malus domestics, relative growth rate, carbohydrate partitioning, sorbitol
Abstract. Absolute and relative fruit growth rates (AGR and RGR) of apple (Malus domestics Borkh.) were calculated from the fruit dry weights of several cultivars harvested periodically following June drop during 1988-90. AGRs were constant or varied slightly, and RGRs generally declined as the season progressed. Generally, both AGR and RGR values were higher for relatively large fruit of several cultivars with similar days to maturity, e.g., 'McIntosh' vs. 'Jonathan' and for summer- vs. fall-ripening cultivars, e.g., 'Stayman' vs. others. An exception was observed in 1990, when 'Golden Delicious' exhibited a higher AGR but lower RGR than 'Rome Beauty', yet ripened 1 month earlier. 'Golden Delicious' AGR and RGR values were lower for both fruit of a pair on a spur than the values for a single fruit on a spur, and the dominant fruit of the pair exhibited higher growth rates than the inferior fruit. Rates of sorbitol accumulation (SAR) by cortex disks incubated in ${ }^{14} \mathrm{C}$-labeled sorbitol solutions in vitro declined as the season progressed. Within a cultivar, SARS were not related to fruit size, nor were differences found between cortex disks from competing fruit on a spur, although SARS were higher for both competing fruit on a spur as compared to that of a single fruit per spur. Due to a positive correlation between RGR and SAR values, the SAR of cortex cells may be regulated in such a manner as to be a physiological constraint on fruit sink strength and growth rate.
\end{abstract}

Although final size of apple fruit is primarily determined by the total cell count per fruit (Lakso et al., 1989), the bulk of dry weight (DW) is acquired during the postcell division period after June drop. Substantive evidence is lacking on the significance of limited carbohydrate availability on fruit growth during this period. The ability of fruit to effectively compete with other metabolic sinks for available carbohydrate will dictate whether or not they achieve their maximum potential size and quality. The competitive status of a fruit is a function of the mobilizing ability, or sink activity, of the cortex cells. Thus, sink activity may represent a "physiological constraint" $(\mathrm{Ho}, 1988)$ on the competitive ability of the fruit.

The daily rate of carbohydrate accumulation by fruit has been expressed as AGR, defined as milligrams DW per day and termed "sink strength" (Daie, 1985). The RGR, defined as milligrams DW per gram per day, has been used to express the sink activity of a fruit. Since temperature influences fruit development (Fischer, 1962), degree-day accumulation rather than days is more appropriate to express developmental time (DeJong and Goudriaan, 1989). Due to the wide diversity of harvest dates among apple cultivars, with both similar final weights at different dates and different weights on the same harvest dates, both AGR and RGR values may vary considerably among cultivars (Hansen, 1977). In stone fruits, an early maturing cultivar expressed a higher RGR during Stage III, or the second phase of rapid growth, than a late-maturing cultivar (DeJong and Goudriaan, 1989). A declining RGR value as fruits age, observed in apple and other species (Forney and Breen, 1985; Lakso et al., 1989; Walker and Thornley, 1977) is related to a diminishing ability to accumulate carbohydrates at the tissue or cellular level (Archbold, 1988; Beruter, 1983; Forney and Breen, 1985; Johnson et al., 1988).

Received for publication 28 May 1991. Accepted for publication 2 Dec. 1991. The investigation reported in this paper (no. 91-10-86) is in connection with a project of the Kentucky Agricultural Experiment Station and is published with approval of the Director. The cost of publishing this paper was defrayed in part by the payment of page charges. Under postal regulations, this paper therefore must be hereby marked advertisement solely to indicate this fact.
Cultivar differences in tomato (Lycopersicon esculentum Mill.) fruit sink activities in vitro were related to differences in wholefruit carbohydrate accumulation (Hewitt et al., 1982). Cultivarspecific growth rates are expressed by apple fruit (Hansen, 1977) and could be a function of the sink activity of the cortex cells, just as aging apple fruit exhibit both declining RGR and in vitro cortex sink activities. Regulation of sink activity at the tissue or cellular level could occur during carbohydrate unloading from the phloem, uptake and membrane transfer by sink cells, or at points of metabolic conversion (Daie, 1985; Ho, 1988). Sorbitol and some sucrose are the principal carbohydrates translocated in apple (Webb and Burley, 1962). Incubation of cortex tissue disks in sorbitol solutions in vitro eliminates phloem unloading as a factor; thus, differences in sink activity would result from variation at the latter two sites of regulation. Adenosine 5'triphosphate (ATP)-dependent sorbitol carrier mechanisms have been described at the plasmalemma and tonoplast and would be potential regulatory points (Beruter and Kalberer, 1983; Yamaki, 1987; Yamaki and Asakura, 1988). In addition, sorbitol dehydrogenase is the primary enzyme responsible for conversion of sorbitol to fructose and could also be a site of regulation (Beruter, 1985; Yamaki and Ishikawa, 1986).

To determine if sink activity of apple cortex disks is related to AGR and RGR among and within cultivars, fruit size, harvest season, or crop load, concurrent assessments of in vivo AGR and RGR and in vitro sorbitol accumulation by cortex disks of several apple cultivars were made over three seasons.

\section{Materials and Methods}

The apple trees used in this study were planted in 1971 (1988 data) and in 1985 (1989-90 data) at the Univ. of Kentucky's horticulture farms in Lexington. The trees were on semidwarf rootstock and annually received routine horticultural care. Apple fruit from two to five trees each of several cultivars were harvested periodically following June drop in the 1988, 1989,

Abbreviations: AGR, absolute growth rate; DW, dry weight; RGR, relative growth rate; SAR, sorbitol accumulation. 
and 1990 seasons. Trees were not thinned in 1988, but were chemically thinned with 2-(1-naphthyl)acetic acid (NAA) after full bloom to visually similar crop loads in 1989 and 1990. Single fruit borne on spurs, a minimum 25 fruit per date in 1988 and 10 fruit per date in 1989 and 1990, were randomly harvested from the periphery of the tree canopies,' unless otherwise noted. For DW determinations, fruit were cut into sections, frozen, and lyophilized before being weighed. Ambient air temperature data from a weather station, 1.8 and $0.3 \mathrm{~km}$ from the 1988 and 1989-90 sites, respectively, were used to calculate degree-day accumulation starting at full bloom using a minimum of $7 \mathrm{C}$ and a maximum of 35C; AGR and RGR values were determined from the mean fruit DWS and cumulative degree days (Causton and Venus, 1981).

On selected dates, cortex plugs were removed from individually weighed fruit with a 6-mm-diameter cork borer and cut into 1.4-mm-thick disks. Disks were held in $3 \mathrm{ml}$ of an ice-cold $1 \mathrm{mMCaCl}_{2}, 10 \mathrm{~mm}$ 2-[N-morpholino]ethanesulfonic acid (MES) preincubation solution ( $\mathrm{pH}$ 6.0) and were gently shaken for 30 min. After $30 \mathrm{~min}$ in the preincubation solution, 10 disks were transferred to $3 \mathrm{ml}$ of the above solution containing $20 \mathrm{mM}{ }^{14} \mathrm{C}$ labeled sorbitol (specific activity 12 to $33 \mathrm{kBq} \cdot \mathrm{mmol}^{-1}$ ) in a 25-ml flask. The disks were incubated for $2 \mathrm{~h}$ at ambient temperature with constant gentle shaking. Subsequently, the disks were washed five times over $30 \mathrm{~min}$ with 3 -ml aliquots of icecold preincubation solution to remove sorbitol from the free space (Beruter and Kalberer, 1983). After the final wash, disks were frozen instantly in liquid $\mathrm{N}_{2}$. Frozen, disks were lyophilized, weighed, ground with a glass rod, and extracted in $2 \mathrm{ml}$ of $80 \%$ ethanol in a $70 \mathrm{C}$ water bath. Radioactivity in aliquots of the extracts was determined by liquid scintillation analysis, and SARS per gram DW per hour were calculated.

\section{Results and Discussion}

Total DW accumulation during 1988 varied among cultivars (Fig. 1A). Cultivar variation in post-June drop AGR and RGR values was also evident (Fig. $1 \mathrm{~B}$ and $\mathrm{C}$, Table 1). The AGR values were constant or varied slightly as the season progressed, while RGR values generally declined, as observed in apple and other species (Forney and Breen, 1985; Lakso et al., 1989; Walker and Thornley, 1977). In 1988, the early maturing 'Tydeman's Red' and 'McIntosh' fruit exhibited higher AGRs than fruit from the other cultivars, and 'Stayman', the last to mature, exhibited the lowest RGR. 'McIntosh' also showed higher total DW accumulation and growth rates than 'Jonathan', which matured shortly after it. The 1988 DW values likely reflected total cell number per fruit, which may have been limited by carbohydrate supplies before June drop (Lakso et al., 1989).

In 1990, 'Jonathan' and 'Golden Delicious' exhibited higher AGR values than 'Rome' (Table 1) during the first interval, while the AGR of 'Golden Delicious' was lowest in the second interval. The RGR of 'Golden Delicious' was the lowest in both intervals. Thus, although there was a general association of higher AGR and RGR values with the earlier-maturing cultivars, similar to that observed in 1989 and during Stage III of two peach [Prunus persica (L.) Batsch] cultivars (DeJong and Goudriaan, 1989), it was not consistent. Some of the year-to-year variability may be attributed to environmental stress and/or intraplant competition for available carbohydrates. The 1990 data also indicated that fruit growth in 1988 was likely carbohydrateIimited, as 1990 AGR values were considerably higher than the 1988 values at comparable sampling dates. The minimal year-
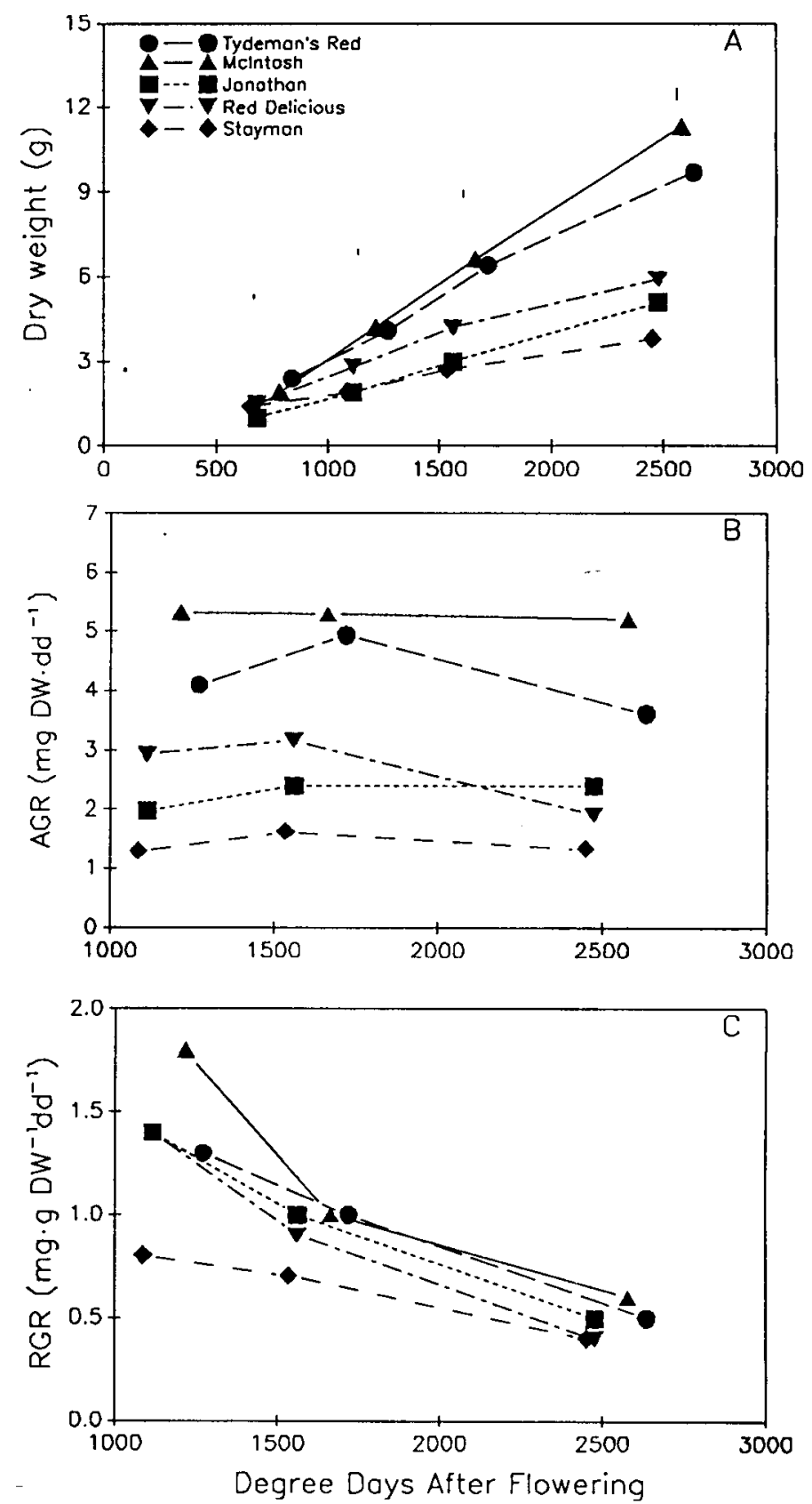

Fig. 1. Apple fruit growth characteristics after June drop, 1988. (A) Total dry weight accumulation. Vertical bars represent SE of the pooled mean for all cultivars at each sampling date. (B) AGR, (C) RGR.

to-year variability in RGR values suggested that RGR is influenced less by carbohydrate supply than is AGR.

The SARS of cortex disks, a tissue-level assessment of RGR, declined as fruits aged (Table 1), as has been observed in apple and other species (Beruter, 1983; Beruter and Kalberer, 1983; Forney and Breen, 1985; Johnson et al, 1988). In addition, differences among cultivars were also evident, similar to the respective RGR values (Table 1), although not to the same degree. Across years and cultivars, SAR was not correlated to AGR ( $r=0.1$, data not shown), but it was positively correlated to RGR (Fig. 2). Thus, sink activity at the tissue or cellular level played a significant role in defining RGR in vivo. In strawberry (Fragaria $\times$ ananassa Duch.) fruit, RGR values were 
Table 1. Apple cultivar fruit growth rates in vivo and fruit cortex disk sorbitol accumulation in vitro, 1988 and 1990.

\begin{tabular}{|c|c|c|c|c|c|c|c|c|}
\hline \multicolumn{2}{|c|}{ Interval } & \multirow{2}{*}{$\begin{array}{l}\text { Bloom }^{\mathbf{2}} \\
\text { to interval } \\
\text { (DD) }\end{array}$} & \multirow[b]{2}{*}{ Cultivar } & \multicolumn{2}{|c|}{ Fruit dry wt $(g)^{y}$} & \multirow{2}{*}{$\begin{array}{c}\text { AGR } \\
\text { (mg DW/DD) }\end{array}$} & \multirow{2}{*}{$\begin{array}{c}\text { RGR } \\
(\mathrm{mg} / \mathrm{g} \mathrm{DW} \text { per } \mathrm{DD})\end{array}$} & \multirow{2}{*}{$\begin{array}{c}\text { SAR } \\
(\mu \mathrm{mol} / \mathrm{g} \mathrm{DW} \text { per } \mathrm{h})\end{array}$} \\
\hline $\mathrm{JD}^{\mathrm{x}}$ & $\mathrm{DD}^{\mathrm{x}}$ & & & Date 1 & Date 2 & & & \\
\hline & & & & & 1988 & & & \\
\hline \multirow[t]{2}{*}{$176-192$} & 428 & 786 & McIntosh & $1.9 \pm 0.8$ & $4.2 \pm 0.8$ & 5.3 & 1.82 & $11.6 \pm 0.5^{w}$ \\
\hline & & 658 & Stayman & $1.4 \pm 0.4$ & $2.1 \pm 0.5$ & 1.3 & 0.79 & $3.4 \pm 0.8$ \\
\hline \multirow[t]{3}{*}{$192-222$} & 876 & 1214 & McIntosh & $6.5 \pm 0.9$ & $11.3 \pm 1.5$ & 5.2 & 0.59 & $4.4 \pm 0.4$ \\
\hline & & 1086 & Stayman & $2.6 \pm 1.0$ & $3.9 \pm 2.3$ & 1.3 & 0.41 & $1.9 \pm 0.3$ \\
\hline & & & & & 1990 & & & \\
\hline \multirow[t]{3}{*}{$155-169$} & 391 & 807 & Jonathan & $1.2 \pm 0.2$ & $3.9 \pm 0.3$ & 7.1 & 3.37 & $22.5 \pm 1.4$ \\
\hline & & 807 & Golden Delicious & $2.0 \pm 0.1$ & $5.0 \pm 0.7$ & 7.7 & 2.31 & $22.7 \pm 1.2$ \\
\hline & & 698 & Rome & $1.1 \pm 0.4$ & $3.4 \pm 0.3$ & 6.0 & 3.05 & $12.2 \pm 1.2$ \\
\hline \multirow[t]{3}{*}{$187-201$} & 423 & 1198 & Jonathan & $6.9 \pm 0.8$ & $13.8 \pm 1.4$ & 18.4 & 2.01 & $6.2 \pm 0.4$ \\
\hline & & 1198 & Golden Delicious & $10.3 \pm 0.6$ & $14.0 \pm 1.7$ & 8.8 & 0.71 & $4.6 \pm 1.4$ \\
\hline & & 1089 & Rome & $5.7 \pm 0.7$ & $10.1 \pm 1.1$ & 10.3 & 1.36 & $6.8 \pm 0.6$ \\
\hline
\end{tabular}

${ }^{2}$ Date of full bloom in 1988 was 111 Julian days for 'McIntosh' and 127 Julian days for 'Stayman', and in 1990 it was 100 Julian days for 'Jonathan' and 'Golden Delicious' and 110 Julian days for 'Rome'.

${ }^{y}$ Mean \pm SE of 25 replicate fruit in 1988 and 10 replicate fruit in 1990, collected at the beginning and end of each interval.

${ }^{\mathrm{x}} \mathrm{JD}=$ Julian days, DD $=$ degree days.

"Mean \pm SE of five replicate fruit.

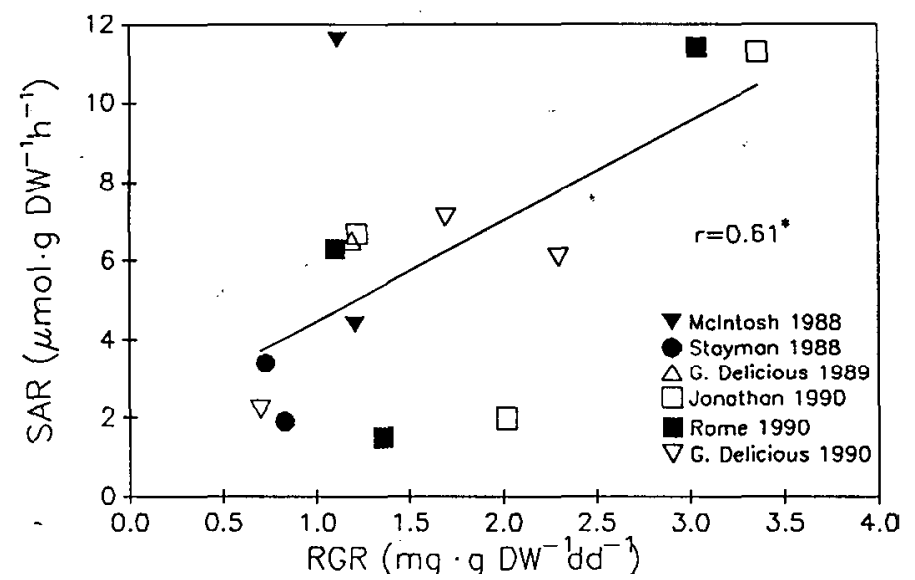

Fig. 2. Relationship between apple fruit cortex SAR in vitro and fruit RGR in vivo across cultivars and years from fruit sampled at varying degree days after bloom. Correlation coefficient significant at $P=$ 0.05 .

related to in vitro sucrose accumulation rates (Forney and Breen, 1985).

Fruit fresh weight was not correlated to SAR as might be expected of fruit cells from a single genotype ( $r=0.02$, data not shown). In tomato and strawberry, size per se was not related to the rate of sucrose accumulation in vitro (Archbold, 1988; Dinar and Stevens, 1982). Thus, SARS of apple cortex disks were consistent within a cultivar if sampled from spurs bearing a single fruit, i.e., not carbohydrate-limited, on one date. However, competition among fruit influenced AGR and RGR values. Both values were lower for each of the two fruit on a spur vs. those for a single fruit, and the dominant fruit, as determined by fruit fresh weight, exhibited higher values than the inferior fruit (Table 2). Although crop load was considered light to moderate, the total carbohydrate accumulated per degree day for both fruit was similar to that of a single fruit. The spur phloem may have limited the total carbohydrate flux such that similar amounts were available to the fruit regardless of number. The dominance effect may also have influenced carbohydrate accumulation rates (Bangerth, 1989).
The SAR values for cortex disks from each fruit of a pair was higher than for a single fruit per spur. Limited carbohydrate availability to the competing fruit may have reduced their soluble sugar levels as compared to a single fruit (Beruter, 1985, 1989), but it is not known if internal sugar concentration can affect carrier-mediated sorbitol uptake. Increasing the external sugar concentration resulted in higher uptake rates (Beruter and Kalberer, 1983; Dinar and Stevens, 1982). Regardless, a higher in vivo RGR was associated with a lower in vitro SAR. The proposed dominance factor affecting RGR may have been reduced or eliminated when the fruit were collected. This result contrasts with results with strawberry, where cortex disks from fruit in inferior positions, with lower in vivo RGR values, exhibited lower sucrose accumulation rates in vitro than those from primary fruit (Forney and Breen, 1985). Results with strawberry may have differed due to the varying RGRs among primary and lower-order fruit sampled at the same chronological age but at different phases of their growth pattern (Miura et al., 1990).

Differences in AGR and RGR values among apple cultivars may be due, in large part, to inherently different rates of carbohydrate accumulation by cortex cells. Respiratory metabolism of imported carbohydrates may be expected to influence the observed AGR, RGR, and SAR values, but it is likely correlated with RGR (DeJong and Goudriaan, 1989; Walker and Thornley, 1977). Thus, including respiratory losses, total carbohydrates import would be greater for those cultivars with relatively high RGRs and SARS. While intraplant competition, dominance effects, and even carbohydrate unloading in the fruit sink may affect AGR and RGR in vivo, a fundamental physiological difference in the ability of cortex cells to accumulate carbohydrate, as expressed in the SARS in this study, would play a critical role in defining maximum sink activity. Hansen (1977) observed cultivar-specific fruit growth rates in vivo but did not determine the source of the variation. The cultivar-specific fruit growth rate appears to be manifest in the ability of cortex cells to accumulate sorbitol. This physiological constraint must occur at points of membrane transfer and/or metabolic conversion. Likely regulatory points occur at the plasmalemma and tonoplast sorbitol carriers and during sorbitol metabolism (Beruter, 1985; Yamaki and Ishikawa, 1986). The rate of sorbitol uptake by 
Table 2. Dominance effects on 'Golden Delicious' apple fruit growth rates" in vivo and fruit cortex disk sorbitol accumulation in vitro, 1989.

\begin{tabular}{|c|c|c|c|c|c|}
\hline \multirow{2}{*}{$\begin{array}{l}\text { Fruit } \\
\text { position }\end{array}$} & \multicolumn{2}{|c|}{ Fruit dry wt $(\mathrm{g})^{\mathbf{y}}$} & \multirow{2}{*}{$\begin{array}{c}\text { AGR } \\
\text { (mg DW/DD) }\end{array}$} & \multirow{2}{*}{$\begin{array}{c}\text { RGR } \\
\text { (mg/g DW } \\
\text { per DD) }\end{array}$} & \multirow{2}{*}{$\begin{array}{c}\text { SAR } \\
(\mu \mathrm{mol} / \mathrm{g} \\
\mathrm{DW} \text { per } \mathrm{h})\end{array}$} \\
\hline & Date 1 & Date 2 & & & \\
\hline $\begin{array}{l}1 \text { fruit/spur } \\
2 \text { fruit/spur }\end{array}$ & $15.5 \pm 2.4$ & $19.4 \pm 5.2$ & 10.0 & 0.54 & $6.5 \pm 1.3^{\mathrm{w}}$ \\
\hline $\begin{array}{l}\text { Dominant } \\
\text { Inferior }\end{array}$ & $\begin{array}{l}15.8 \pm 0.9 \\
10.4 \pm 1.1\end{array}$ & $\begin{array}{l}18.9 \pm 1.5 \\
11.6 \pm 1.4\end{array}$ & $\begin{array}{l}7.7 \\
3.1\end{array}$ & $\begin{array}{l}0.46 \\
0.24\end{array}$ & $\begin{array}{l}10.1 \pm 1.5 \\
11.1+2.2\end{array}$ \\
\hline
\end{tabular}

${ }^{2}$ Interval 224-238 Julian days or 2621-3010 cumulative degree days after flowering. Date of full bloom was 108 Julian days.

${ }^{y}$ Mean \pm SE of 10 replicate fruit collected on 224 (Date 1) and 238 (Date 2) Julian

days.

${ }^{\mathrm{x}} \mathrm{DD}=$ degree days.

"Mean \&SE of five replicate fruit $\mathrm{x}$ two dates.

apple cortex disks in vitro is related to the rate of fructose formation (Beruter and Kalberer, 1983), but cuhivar differences in the activity of sorbitol dehydrogenase have not been investigated. At high crop loads with significant competition for Iimited carbohydrates, sink activity could play an important role in determining carbohydrate allocation and fruit growth rates in the context of whole-plant biomass accumulation and allocation.

\section{Literature Cited}

Archbold, D.D. 1988. Abscisic acid facilitates sucrose import by strawberry fruit explants and cortex disks in vitro. HortScience 23:880881.

Bangerth, F. 1989. Dominance among fruits/sinks and the search for a correlative signal. Physiol. Plant. 76:608-614.

Beruter, J. 1983. Effect of abscisic acid on sorbitol uptake in growing apple fruits. J. Expt. Bet. 34:737-743.

Beruter, J. 1985. Sugar accumulation and changes in the activities of related enzymes during development of the apple fruit. J. Plant Physiol. 121:331-341.

Beruter, J. 1989. Carbohydrate partitioning and changes in water relations of growing apple fruit. J. Plant Physiol. 135:583-587.

Beruter, J. and P. Kalberer. 1983. The uptake of sorbitol by apple fruit tissue. Z. Pflanzenphysiol. Bd. 110:113-125.

Causton, D.R. and J.C. Venus. 1981. The biometry of plant growth. Edward Arnold, London.

Daie, J. 1985. Carbohydrate partitioning and metabolism in crops. Hort. Rev. 7:69-108.

DeJong, T.M. and J. Goudriaan. 1989. Modeling peach fruit growth and carbohydrate requirements: Reevaluation of the double-sigmoid growth pattern. J. Amer. Soc. Hort. Sci. 114:800-804.

Dinar, M. and M.A. Stevens. 1982. The effect of temperature and carbon metabolism on sucrose uptake by detached tomato fruits. Ann. Bet. 49:477483.

Fischer, D.V. 1962. Heat unit accumulation and number of days re- quired to mature some pome and stone fruits.in various areas of North America. Proc. Amer. Soc. Hort. Sci. 80:114-124.

Forney, C.F. and P.J. Breen. 1985. Growth of strawberry fruit and sugar uptake of fruit discs at different inflorescence positions. Scientia Hort. 27:55-62.

Hansen, P. 1977. The relative importance of fruits and leaves for the cultivar-specific growth rate of apple fruits. J. Hort. Sci. 52:501508.

Hewitt, J. D., M. Dinar, and M.A. Stevens. 1982. Sink strength of fruits of two tomato genotypes differing in total fruit solids content. J. Amer. Soc. Hort. Sci. 107:896900.

Ho, L.C. 1988. Metabolism and compartmentation of imported sugars in sink organs in relation to sink strength. Annu. Rev. Plant Physiol. 39:355-378.

Johnson, C., J.L. Hall, and L.C. Ho. 1988. Pathways of uptake and accumulation of sugars in tomato fruit. Ann. Bet. 61:593-603.

Lakso, A. N., T.L. Robinson, and R.M. PooL 1989. Canopy microclimate effects on patterns of fruiting and fruit development in apples and grapes, p. 263-274. In: C.J. Wright (cd.). Manipulation of fruiting. Butterworth, Boston.

Miura, H., S. Imada, and S. Yabuuchi. 1990. Double sigmoid growth curve of strawberry fruit. J. Jpn. Soc. Hort. Sci. 59:527-531.

Walker, A.J. and J.H.M. Thorney. 1977. The tomato fruit: Import, growth, respiration and carbon metabolism at different fruit sizes and temperatures. Ann. Bet. 41:977-985.

Webb, K.L. and J.W.A. Burley. 1962. Sorbitol translocation in apple. Science 137:766.

Yamaki, S. 1987. A'IT-promoted sorbitol transport into vacuoles isolated from apple fruit. Plant Cell PhysioL 28:557-564.

Yamaki, S. and T. Asakura. 1988. Energy coupled transport of sorbitol and other sugars into the protoplasm isolated from apple fruit flesh. Plant Cell Physiol. 29:961-967.

Yamaki, S. and K. Ishikawa. 1986. Roles of four sorbitol related enzymes and invertase in the seasonal alteration of sugar metabolism in apple tissue. J. Amer. Soc. Hort. Sci. 111:134-137. 